\title{
Business schools in crisis
}

\author{
F. Phillips ${ }^{1,2^{*}}$ (D, C. H. Hsieh², C. Ingene $e^{3}$ and L. Golden ${ }^{4}$
}

\author{
* Correspondence: \\ fphillips@saturn.yzu.edu.tw \\ 'Stony Brook University, Stony \\ Brook, USA \\ ${ }^{2}$ Yuan Ze University, Taoyuan City, \\ Taiwan \\ Full list of author information is \\ available at the end of the article
}

\begin{abstract}
Economic, political, and demographic changes, technological advances, two crashes of the economy, ethical scandals, and other developments in the business environment have strained the roles and enrollments of American universities' business schools. The b-schools have not responded adequately. Prevailing theories in many of the management disciplines have broken down, partly as a result of the same environmental changes. Again, schools and curricula have not adapted. Collegiate business education is in dire crisis. In this paper we document the crisis, note measures that have been taken - both constructive and otherwise - and make further suggestions for improving the situation.
\end{abstract}

Keywords: Business education, MBA, Business schools, Management, Ethics

\section{Introduction}

Let's not mince words: Our MBA graduates marched out and destroyed the world financial system. Few in academe have stepped up to take responsibility. We have yet to hear a professor say, "I taught those people, and I'm sorry."

MBA curriculum, taught in US b-schools, has become a race to the bottom, with courses getting shorter and easier as MBA programs proliferate and compete for students. ${ }^{2}$

Harvard's Rakesh Khurana notes there's no longer a consensus on what constitutes a core curriculum in business. There is nothing even resembling a unified body of management knowledge. "It's not clear what an MBA consists of anymore," he says.

Small wonder, when US b-schools lack leadership. The Dean that is selected is the candidate with the most fund-raising ability, and at least enough publications to pretend to scholarly respectability. She or he is not required to show the academic leadership that could produce a coherent, relevant curriculum. In any case the Dean will spend, on average, only five years in office before moving on to another job - and a quarter of them spend only three years as Dean (Bradshaw 2015).

Reports in Forbes, Chronicle of Higher Education, Harvard Business Review and others reveal simultaneous intellectual crises in the disciplines taught in b-schools. The foundations of Economics (DeLong (2011), "Economics in Crisis"; see also Krugman (2011)), Strategy (Denning (2012), “What Killed Michael Porter's Monitor Group?”), Psychology (Shea (2011), "Fraud Scandal Fuels Debate Over Practices of Social Psychology"), Finance (Galbraith (2010), "Why the 'Experts' Failed to See How Financial Fraud Collapsed the Economy"), venture capital (Mulcahy et al (2012) on the Kauffman Foundation's conclusion that “...the VC model is broken"), and Management (Bloom et al (2012), “Does Management Really Work?”) have shaken.

(C) 2016 The Author(s). Open Access This article is distributed under the terms of the Creative Commons Attribution 4.0 International License (http://creativecommons.org/licenses/by/4.0/), which permits unrestricted use, distribution, and reproduction in any medium, provided you give appropriate credit to the original author(s) and the source, provide a link to the Creative Commons license, and indicate if changes were made. 
Why this happened all at once is still mysterious, though in large part we may attribute it to b-schools being slow to adapt to a new and vastly different business environment. It is one reason Khurana says "you're not going to learn much" in the MBA program. Students take the MBA not for its irrelevant content, but simply to show potential investors and employers that they are smart, hard-working people with good personal networks. Prospective students looking at escalating tuitions are going to find cheaper ways to demonstrate these qualities.

No one in the university admits responsibility for this. No one in the leading research universities gets tenure for redesigning curricula. The teaching colleges follow the lead of the research universities. Who then will change what b-schools teach students? William Holstein (2013) is right: "Business schools are facing a crisis of global irrelevance."

Denial of the crisis among social scientists has largely been of the "There's always a few bad apples" variety. Denial seems to run deepest among economics and finance faculty and professionals. Ironically, "In Defense of Financial Innovation" 3 was published the same day as "Big Banks Fined \$5.7 Billion After Pleading Guilty to Global Currency Conspiracy."

Davies (2012) writes that the Chicago School...

...has mounted a robust defense of its rational expectations-based approach, rejecting the notion that a rethink is required. The Nobel laureate economist Robert Lucas has argued that the crisis was not predicted because economic theory predicts that such events cannot be predicted. So all is well.

And there is disturbing evidence that news of the crisis has not yet reached some economics departments. Stephen King, Group Chief Economist of HSBC, notes that when he asks recent university graduates (and HSBC recruits a large number of them) how much time they spent in lectures and seminars on the financial crisis, "most admitted that the subject had not even been raised."

In preparing this paper we have tried to find credible articles supporting this denial. However, we conclude the crisis is real.

In what follows, we write in more detail about the crisis in each of the mentioned disciplines and its interaction with the changing business environment and with business education. Drawing on expert opinion and literature review, we then connect the discussion to the business school's mission, organization, and curriculum, outlining the key considerations that will frame improvement or solution. The paper concludes with a set of recommendations for business schools.

\section{Changes in the business environment bring challenges to the business disciplines}

What struck me during my deanship was the speed at which we all risk becoming "out of date" in a world in which the rate of transformation is arguably unprecedented.... The environment that graduates enter may bear little or no relationship to that of a few years previously. 


\section{- Martin Binks, Former Dean, Nottingham University Business School ${ }^{5}$}

The changes include globalization, technological advances, growing income and wealth inequality, declining social mobility, big data, climate change (see e.g., Phillips 2006; Howard-Grenville et al. 2014; Phillips 2014), the rise of China (and more recently of India), demographic shifts, the sharing economy, and U.S. détente with Iran and Cuba.

Satell (2015) comments,

Competitiveness is no longer determined by how efficiently we move around men and materiel, but in how we connect to informational resources. Enterprises need to manage organizational resources, but no longer derive the same scale advantages they used to.

[Therefore] we are no longer sure what businesses we are in. There was a time when being in banking or electronics or manufacturing had a specific meaning. Now, bankers must understand algorithmic trading, techies lend money, pharma companies invest and manufacturers design computerized devices just to do their work. We often have little idea where the next opportunity or threat may come from. And not knowing what business you are in, from year to year or less, makes it harder to figure out exactly what competitive advantage, exactly, we hope to sustain.

Doing and teaching business will be much more difficult until we can come to a new, and possibly radical, set of perspectives that acknowledge these changes.

The remainder of this section looks at the obstacles and opportunities for a number of business-related disciplines.

\section{Economics}

At the current state of knowledge there is no theoretical reason or empirical evidence to support the notion that all the growth of the financial sector in the last forty years has been beneficial to society.... Furthermore, I am not aware of any evidence that the creation and growth of the junk bond market, the option and futures market, or the development of over-the-counter derivatives, are positively correlated with economic growth. - Luigi Zingales (2015)

Should governments spend and borrow more to revive a dreary economy? Or impose austerity? There are established economic theories that argue either way. "Governments unanimously put their faith in the second [of these]. The consequences of this choice are clear. It is now pretty much agreed that fiscal tightening has cost developed economies five to ten percentage points of GDP growth since 2010" (Skidelsky 2012).

Long ago, economist Robert Kuttner wrote that economists, who regard equilibrium as inevitable in commodity markets, then make the mistake of thinking equilibrium is desirable. That is still a problem affecting university curriculum. Economists' overarching principle, say Atkinson and Lind (2013), has been "maximize efficiency." But "the goal of economic policy should not be to maximize static efficiency (the 'right' allocation of widgets), but to create inefficiency - in the sense of disruptive innovation that makes 
widgets worthless." ${ }^{16}$ This view needs to become more current in the classroom, as curriculum now bends further toward innovation and entrepreneurship.

As social and business problems become more complex, students need to gain a "systems" perspective. They are not getting one in the classroom. In a comment under Davies (2012) column, economist Gerald Silverberg wrote, "Most of the shortcomings of mainstream (rational expectations, general equilibrium) theory have been known for years: equilibrium rather than dynamics; lack of agent interaction ...; perfect, selfconsistent behavior rather than ...bounded rationality that is additionally heterogeneous and endogenous; unique stable equilibria vs. combinations of negative and positive feedbacks resulting in multi-equilibria and more complex dynamic behaviors." Silverberg cites the evolutionary economics work of Simon, Nelson and Winter, Day, Mandelbrot, and the Santa Fe Institute. He notes these works rarely show up in the curriculum, and lays the blame on "the sociology of US graduate education in economics."

\section{Finance}

"I won't hire from Wall Street any more. All those people know is how to suck value out of a company, not how to add value to it." - An entrepreneur

Foroohar (2014), citing the "widely known" fact that most mergers and acquisitions knock down shareholder value, wondered why M\&A activity was up in 2014. Her answer? "It's an easy way to make a quick buck and please Wall Street. Increasingly, business is serving markets rather than markets serving business, as they were originally meant to do in the capitalist system."

Foroohar cites Mukunda's (2014) finding that 78 \% of surveyed CFOs "would give up economic value and $55 \%$ would cancel a project with a positive NPV - that is, willingly harm their companies - to meet Wall Street's targets." Otherwise, activist shareholders will agitate for their dismissal, according to Foroohar - despite that the challenges of the new business environment, which we have listed above, are problems "which will take years, if not decades, to resolve.... All this will put American firms at a distinct disadvantage against global competitors with long-term mindsets.... [By] 2025, 7 of 10 of the largest global firms are likely to come from emerging markets, and most will be family-owned [or SEO] businesses not beholden to the markets."

\section{Strategy}

Strategy is stuck. - McGrath (2013).

"As the impact of the technology revolution became evident in the 1990s the days of corporate strategy as a dominant discipline began to wane," wrote Sull, Homkes, and Sull (2015), "The ability of the organization to execute a strategy - and almost any strategy - surpassed the usefulness of formulating a strategy."

Sull et al. asked managers why execution fails. Answers: no cooperation across functions and business units, and inability to adapt to changing market conditions.

Though cautioning against undisciplined violation of strategy, Sull et al. do not advise inflexible adherence to outdated strategies. "When managers come up with creative 
solutions to unforeseen problems or run with unexpected opportunities, they are not undermining systematic implementation; they are demonstrating execution at its best. Such real-time adjustments require firms to be agile." As McGrath (2013) concludes, "Sustainable competitive advantage is now the exception, not the rule".

The false mystique of the CEO master strategist who can foretell the future, says Denning (2012), embraces the notion that strategy is a fundamentally different from operational planning and requires a different breed of more highly paid person. In a vicious circle, this fallacy expands the pay gap between top execs and the rank and file, worsens income inequality in America, encourages the rich to invest in paper and land rather than in factories, and thus changes the business environment still further - requiring even more adjustment on the part of business schools. B-schools can end this cycle by changing the way they teach strategy.

\section{Psychology}

A recent large meta-study showed the results of most published psychology experiments cannot be replicated (News Staff 2015). The popular press eats up surprising results in psychology, so researchers are tempted to demonstrate surprising results. The meta-study showed that more surprising results showed less replicability than more mundane results.

This follows Henrich's (2005, 2010; see also Watters 2013) groundbreaking intercultural work, which showed that many canonical psychology results, based on experiments on US university students, are contradicted when the experiments are repeated using subjects of other cultures and places. Several recent cases of research fraud have been uncovered (Shea 2011).

We see many of the same problems in empirical research in the traditional business fields. Marginally sufficient sample sizes, convenience-sample studies analyzed and interpreted as if they were random-sample studies, careless claims about scope of a study's applicability. Researchers then expect industry managers to take the "recommendations" section of the study as a spur to action. It is difficult for a poorly funded researcher under publication pressure to conduct a primary data study with an $n$ of more than several hundred. Yet as one insurance executive told a $\mathrm{PhD}$ class, his company would not think of designing a policy on the basis of less than a random sample of twenty thousand.

\section{Entrepreneurship}

So, in effect, the Coasean model has been turned on its head. Technology has minimized transaction costs, while organizational costs have become a heavy burden. Nimble startups can access manufacturing resources, talent, financing, computing power and just about anything else you can imagine and still be price competitive with the big guys - Satell (2015).

Satell's statement implies entrepreneurship is no longer a course subject separate from "conventional" big-company management. Entrepreneurs and MNC CEOs are competing on the same playing fields of information/communication technology and social networking. The difference is that the big firms use their incumbent's advantage, 
their wider connections, and their bigger war chests to minimize taxes, influence legislation, and maintain the illusion that they are still different and more deserving.

The Kauffman Foundation showed that venture capitalists' returns on their funds are (considering their fee structure) inferior to those of stock index funds (Mulcahy et al. 2012). The VCs nonetheless write term sheets giving them a firm upper hand over their entrepreneurs (Mims 2015), sometimes much to the detriment of the latter. The universities feed this unfortunate system. "We prepare entrepreneurs to be eaten by VCs whose returns are no better than those of stock index funds" (Rao 2012).

\section{Management}

"The global financial recession and the collapse of investment capitalism (surely not planned by anyone) make it quite clear that top executives are simply not able to choose future directions. Despite this, current management literature mostly continues to avoid the obvious - management's inability to predict or control what will happen in the future. The key question now must be how we are to think about management if we take the uncertainty of organizational life seriously".

- Ralph Stacey (2009)

A Gallup survey showed (Otani 2015) that half of all US employees who quit their jobs do so to get away from bad bosses. See also Slaughter (2015). Despite university and corporate training, and company slogans, aimed at flattening org charts, celebrating failure, boldly innovating and so on, "bosses are rewarded for cutting rather than building" - laying off employees, offshoring operations, and reducing benefits. As the resulting cognitive dissonance flows completely up and down the hierarchy, everyone is distressed and "dysfunction is the norm in the American workplace." As a remedy, Gallup's chief scientist advocates promoting employees to management based primarily on their "natural talent to motivate others and engage workers." (We note that he said 'natural talent,' rather than 'business education.') The results of Sull et al. (2015) agree with those of Gallup.

\section{Human resources}

One of the most important problems in technology is hiring qualified engineers, and yet our industry is terrible at it. - Thomas Ptacek (2015) ${ }^{7}$

After roughly 115 years of Human Resources studies, we still do not know how best to make hiring decisions. Employers are conducting varied experiments (e.g., Feintzeig 2015). This is admirable, but the experiments are wild empiricism, with no theoretical underpinning.

\section{Ethics}

Harvard Business School... could sooner prevent earthquakes than make a primary contribution to ethics in theory or practice. - Joe Coates 
Coates (1994) makes the interesting point that the Greek philosophical tradition and the Abrahamic religions prescribe ethical relationships "in terms of man-to-man, man-to-God, [and] man-to-institution," as well as nation-to-nation, but are "bereft of an ethics of institution-to-institution and institution-to-man".

As a result, Coates says, many arguments that we frame in terms of business ethics would be better framed in other terms having firmer philosophical or logical foundations. And due to the limitations of the Western philosophical heritage, he says, we are poorly equipped as educators to teach ethics in an age when corporations are becoming more powerful than nation-states. We are hard pressed to stretch the Golden Rule - perhaps the one ethical principle we can all agree on - to a full semester course.

We will say more about ethics education below.

\section{The role of accreditors}

Accreditation as a process to certify that institutions are not diploma mills is valid. Everything else is an overreach. - Anonymous commenter on Wheelan and Elgart 2015.

Universities are subject to external controls that somewhat constrain how fast we can change. Accreditors want credit hours, not skills. They want approval authority over the fraction of online courses that can be credited toward a degree. The ability of accreditors to change quickly is even less than that of universities.

Accreditors want to see that each b-school has a strategy and is following it. As a result, b-schools stick to a course of action between accreditation visits, in order to show their adherence to, and progress against, a stated strategy. This occurs even when it is obvious to dean and faculty that, due to new knowledge and market forces, a change in strategy is urgently imperative. Colleges must be freer to revise strategies, and to experiment with new educational forms.

The AACSB is the premier US professional accrediting body for b-schools. One of their national meetings took place at the height of the Enron crisis. Seated in the audience, one of us eagerly awaited a signal from AACSB officials reaffirming the importance of ethics education in the business curriculum. Astonishingly, the word "ethics" was uttered neither by them nor by any of the academics in attendance. Instead, the luncheon speaker - the CEO of Tupperware Corp. - was the only human being in the three-day meeting who so much as mentioned ethics.

So no faculty attendees heard a thing about ethics from their peers, and naturally, their students didn't hear anything new about ethics from their professors. Ten years after the MBAs trashed Enron, its employees' pensions, and its auditor, new MBAs inflated and popped the housing bubble. Swanson and Frederick also noted AACSB's non-reaction in the Enron times, wrote about it (2003), became activists in the matter of AACSB's policy on business ethics, and reported in a follow-up piece (2015) that no progress was evident.

A number of studies, mentioned in Wheelan and Elgart (2015), criticize the high cost of regional accreditation. Wheelan (President of the Southern Association of Colleges and Schools Commission on Colleges) and Elgart attempt to discredit these studies. Commenters on the paper do a thorough job of highlighting Wheelan and Elgart's 
fallacies in rhetoric, though it does seem possible that some accreditation costs noted by the studies are commingled with federal grant compliance costs. Yet on the other hand, professional schools undergo the added costs of specialized accreditation - AACSB and the like, in the case of business schools.

Attendees at AACSB's (very expensive) 2015 meeting complained that (i) none of the sessions' titles matched their content, and (ii) the many newly added reporting requirements evidently benefited AACSB but not the universities. The organization seems to be prestigious because it is prestigious, famous for being famous. It must reform. Otherwise all it will take is one influential individual to stand and say the emperor has no clothes, and the empire will tumble down.

Perhaps that person is Hunter R. Rawlings III, former president of the prestigious Association of American Universities, who says (Rawlings 2016), "Accreditation... not only is outmoded but threatens to taint our entire enterprise".

\section{Business and society}

The main positive effect of quantitative easing was on asset prices - chiefly financial assets. But greater wealth for the rich does not necessarily produce much extra spending. It does increase inequality and threaten asset bubbles, which could lead to a new financial crash. - Skidelsky (2012)

A word about money: In one sense it is not the university's job to create millionaire alumni. In another sense, we love to do so because it creates an opportunity to ask them to donate to dear alma mater. Either way, we should take a neutral stance on the matter of money, teaching that amassing it is neither virtuous in itself nor the opposite.

However, few would argue the moral equivalence of productive investment that results in improved goods and services, and non-productive rent-seeking, e.g. speculation. (This is despite that GNP numbers notoriously do not make this distinction.) Even an organ such as Forbes (Denning 2012) agrees, "The purpose of business is to add value for customers and ultimately society".

In fact, the states charter corporations in the expectation that the corporations will add such value. This first and most basic principle of corporate social responsibility (CSR) should not be given short shrift in the classroom.

It is curious that California and some other states have created a new corporate form, the "B-corporation," that is for-profit but exists specifically for social benefit. Curious because examined logically, it seems to give a free pass to $\mathrm{C}$ - and $\mathrm{S}$-corporations as regards CSR. ${ }^{8}$ Legislators and the press have not adequately explained this.

\section{Business school mission}

Critics ask, "What's the real value of a college education?" If a b-school grad is prepared specifically and exclusively for his/her first post-college job, and that job ends, then the value of the college education wasn't much. Let's prepare students for careers, and moreover, for the several careers in serial that they will probably experience in their lifetime.

"60 \% of employers complained that job applicants lack interpersonal and communication skills. They can pass a calculus exam, but they can't identify or solve problems on the 
job, or negotiate, or lead a meeting." ${ }^{9}$ These things CAN be taught in a classroom. Let's make sure we are doing it.

Grant Cornwall, president of Rollins College, agrees that "post-secondary schools should not simply be job training centers." "Is education for the next job?" Cornwall asks. "If so, then that kind of training is great for the student and our economy. But I have to mention the other - education that prepares students for a full career" (Mathewson 2015).

Benton (2008) makes the point that excessive vocational focus in an institution of higher education can exacerbate anti-intellectualism and the general dumbing-down of America. Skilled employees lacking perspective make bad business decisions, and both poison the business environment. How long can short-termism in business survive in a steadily deteriorating business environment of crumbling infrastructure, decaying neighborhoods, and public mistrust? Not long: Ethologists tell us that only members of dying species defecate in their own nests. Gorillas (which do this) seem to know they're on the brink of extinction. Do public corporations know it about themselves?

A faculty member at a top b-school told one of us, "We have to prepare students to get a job." "But what about the university's mission to graduate well-rounded, wellinformed and responsible citizens?" asked the interlocutor. "Don't be naïve," the lecturer replied, "That's past and gone".

We hope not.

\section{Running the business school more like a business?}

The article linked in footnote 7 is the latest in a recent, unfortunately large, number of wrong-headed pieces on why universities should be run "more like a business." That sentiment is broadly false, but the underlying point that times are changing does mean that some adjustment is called for on the part of universities.

Not a radical change, in our opinion. Universities have existed, in more or less their current business model, for 1700 years. Contrast this with a history of about 150 years for the modern corporation model, and much shorter histories for specialized business forms, like VC firms. If an industry leader says, "The university needs to change its business model," our best response would be, "Talk to me again in another thousand years, and we'll see whose model has survived." Seventeen hundred years means universities are answering a need that is not just transitory. The Internet is not the first technological revolution to come along; the university has persisted through several others.

Indeed - as signaled by the re-privatization of Dell Corp. - the age of the public corporation may already have run its course. Konczal (2015) attributes this to the shareholder power movement: "Research now finds that private firms invest more [in innovation and growth] than similarly situated public ones, while the corporate sector as a whole now returns virtually all profits to shareholders in the form of dividends and buybacks.... Where finance used to get money into firms, now finance is about getting money out of them".

Our hypothetical industry leader (and we've heard the same from some real ones) is forgetting who the university's most important stakeholder is. Our students and their parents - not companies - pay tuition. Especially in the US, companies don't want to pay for training their own employees. They are eager to get something for free from 
the government, and they think public universities ought to train students to "hit the ground running" on their first day of employment after graduation.

Students do want to be employable upon graduation, and particularly in the case of business students, it is the reason they're paying tuition. Yet they have chosen to attend university, not a trade school. At some level they understand that it's the university's job to prepare them for a career, not for a particular job. Blogger Arnold Kransdorff has substantiated ${ }^{10}$ (using BLS data) that "today's learner - i.e. tomorrow's employee - will have 10-14 different jobs by the age of 38. Currently, the median average over the whole of a typical 45 -year working lifetime among Fortune 500 companies is already 12 [jobs], with job tenures of just 12 months for many".

So it's worthwhile to push back against industry's assertiveness. ${ }^{11}$ Ask CEOs, "OK, you say that's what you want. Are you paying your fair share?" Even if the answer is "yes," the university must consider to which constituency it owes what investor Jason Calacanis (2015) calls "the highest moral commitment." The university's highest moral commitment is to the student.

\section{Business school differentiators}

"The world keeps changing every day. If you don't change, you'll be left behind."

- Alibaba Executive Chairman Jack Ma

Back in the day, b-schools led the business world, sending out new ideas and techniques. Now, b-schools react to the business sector, and far too slowly - especially compared to journalists, who turn around in-depth analyses very fast. Of what use is the b-school?

We should not confuse technical skills with knowledge. Teamwork, socialization, character-building, learning how to learn, and developing the commitment to keep on learning, are all things that the university more or less uniquely provides, and are difficult to develop via online courses or short courses.

“'The explosion of all the different things that aren't universities, their presence in the learning ecosystem, will both force and allow universities to re-center themselves around the kind of learning that can't take place in other kinds of settings," says Randall Bass, vice provost for education and professor of English at Georgetown University.' Good point. Students can learn from Khan Academy, online university courses (maybe MOOCs), professional association short courses, computer schools, boot camps, the Internet generally. How can we duplicate, partner with, or effectively complement these sources?

\section{Liberal arts, social sciences, and business disciplines}

"The lobby was as cold and damp and empty as the soul of a Wharton MBA."

- Corporate America (a novel by Jack Dougherty)

Shall we accuse Jack Dougherty of literary hyperbole? Perhaps. Yet a line like that in a bestseller is less than a PR coup for Penn. Before the advent of modern b-schools, companies - even Wall Street banks - hired liberal arts graduates. There's a lot to be 
said for this practice, and businesses would be wise to return to it. Those grads had a sense of history, a way with words, and some idea how their actions would affect society. Unlike, need we point out, the ones who designed collateralized debt obligations.

\section{Liberal arts}

Richard Tedlow is a Harvard business historian who moved to Apple to head the company's "Think Different Corporate University." Tedlow calls the school a "therapeutic alliance between technology and the liberal arts" (Lashinsky 2015). The world's most capitalized company believes this combination is the best one for preparing high tech employees.

Matt Sigelman, CEO of Burning Glass Technologies agrees: "Even in very technical jobs, Burning Glass Technologies' data shows one-quarter to one-third of skills employees need are soft skills, the type that are taught in liberal arts programs." (Mathewson 2015).

Rollins College President Cornwall “doesn't agree with the narrative that liberal arts programs are losing relevance" (Mathewson 2015). Fall and Gaposchkin (2015) claim the same for the medical field:

In today's professional world, obtaining information is not nearly as important as learning what to do with it.... What medical students need is not more information, but rather more and better training in how to think about that information. For a safer health-care system, medical education needs more effective ways to teach future doctors how to think critically and solve problems about health and disease; it needs to draw some core lessons from the classical liberal arts approach.

When ["Jones"] showed his new creation to... the university's intellectual property arm... the people there quickly introduced him to "Smith," a former student at [the university's] School of Management. The two formed a partnership..., with Jones as the creative inspiration and Smith as the business head and CEO. Smith has a somewhat different definition of Bandojo than Jones' "electronic musical instrument." He calls it a platform or single interface for playing multiple instruments.

\section{- Albuquerque Business Journal}

Talk about sucking value out! Replacing the straightforward and descriptive "electronic musical instrument" with the obfuscatory "platform or single interface for playing multiple instruments," a phrase that only a venture capitalist could love? We have disguised names in this recounting. This was to avoid embarrassing the principals, though we are not sure they deserve the courtesy. It is hard to imagine a liberal arts grad perpetrating "a platform or single interface for..."

In fact, Forbes has announced, “That 'Useless' Liberal Arts Degree Has Become Tech's Hottest Ticket" (Anders 2015). Business administration is not the hottest ticket. The importance of the liberal arts for career preparation is echoed by Hunter Rawlins III (2016) and by Carol Geary Schneider (Riddell 2016), who are respectively retiring as presidents of the Association of American Universities and the Association of 
American Colleges \& Universities, with Schneider noting that "a professional will have to navigate complex social, cultural and political environments on top of simply practicing the skills needed for the field".

\section{Social sciences}

"By committing themselves to fiscal tightening, finance ministers gave themselves scope for some fiscal loosening. Proclaiming fiscal virtue enabled them to practice fiscal vice. They could create a fiscal illusion by cutting less than they promised. Most finance ministers did exactly that." - Skidelsky (2012)

Atkinson and Lind (2013) note that among social scientists, neoclassical economists have "largely been able to marginalize any other disciplines or approaches, giving them a virtual monopoly on economic policy advice." The fact that this policy advice has been wrong-headed is due to economists' "philosophical disagreements about human nature and the role of government." As economists in general have not taken courses in human nature, nor been exposed to the dark underbelly of drafting and passing legislation, none of this comes as much of a surprise.

It seems clear that economics students need more exposure to psychology and sociology. The "multiple perspectives" (Linstone and Mitroff 1994) provided by the several social sciences are essential as we attack the "big problems" of today's world. The social sciences may be ailing, but we must not let the budget-cutters axe them in their moment of weakness. We need stronger, reformed social sciences for the health of business education and for the health of the nation.

\section{A word about language}

One of us teaches (in English) occasionally in Peru, a country that enjoys enormous Chinese investment in mining. There, Spanish-English bilingual MBA students are making sure their children learn Chinese as well as English and Spanish. The first generation of people conversant in all three of the world's most widely spoken languages will be Latin American. This will give them great advantage in international business, which today is almost the only kind of business.

In Colombia and Venezuela (due to emigration of "Moorish" families from Spain during the Inquisition) many speakers of English and Spanish also know Arabic, the world's fourth most widely spoken language. As the saying goes, the word for a person who speaks three languages is "trilingual"; two languages, "bilingual"; and only one language, "American." Specifically, an American from the USA.

This must change if American (USA) businesses are to remain competitive in a globalized world, and the place to make the change is in the university, if not in K-12.

\section{Other curriculum issues}

The new president of the University of Texas at Austin promises the creation of new interdisciplinary centers on campus (Roush 2015). "The big questions that we face as a society, as a nation, and as a state don't fit into neat disciplinary boxes."

More than ten years ago, for the first time, published social science papers citing works outside their discipline outnumbered those that cited only within-discipline (Van 
Noorden 2015) and have continued to outnumber pure disciplinary works. This is a worldwide statistic; the United States ranks 7th among countries publishing interdisciplinary works in all sciences. Van Noorden shows that interdisciplinary publications are cited less than disciplinary papers in the three years following publication, but the situation reverses as more years pass.

Vital interdisciplinary studies will require re-examined faculty reward structures.

\section{Teaching}

The professor's role is indeed changing. We don't believe lectures will disappear. But we do hope profs don't "lecture from the book." There is too much information on the Internet, much of it erroneous. A good role for faculty is to sort through the online drivel and select what's most important for students to see and to have explained to them. This function alone justifies tuition. However, professors should be mentors and role models as well.

We were struck by what one Northwestern University professor said many years ago: "My FORTRAN programming has got rusty. I ought to teach a course on it." Humorous, but the remark highlights that professors too need to embrace lifelong learning (indeed it is easier and cheaper for us to do so, because we work right here at the university, and we have doctoral students who can bring the leading-edge literature to our attention) and that teaching is an excellent way to learn and to deepen learning.

Being a role model means being willing and able to learn new things just as - or better than - we want our students to. In this regard, another recent article quoted another misguided dean: "Employers now want Ruby on Rails coders. You don't need a 3-credit course to teach Ruby on Rails, and I can't hire faculty to teach a course that may be obsolete in 18 months." Solution: Make R-on-R one replaceable module in a semester course on Modern Programming Environments (or some such), and use current faculty who, like the Northwestern prof, want to learn by teaching.

Frick (2015) conducted a study, and cited another one, both of which showed that CEO success is better explained by luck than by knowledge or skill. This is possibly another indictment of our teaching. However, let's put a constructive spin on it: Luck comes to the well-prepared, so let's teach students how to recognize opportunity.

\section{Remedial efforts to date}

There are rays of hope - though as yet precious few - for US b-schools. Swanson and Frederick (2003) report that Northwestern University's Kellogg School has launched a 'Business and Its Social Environment' major. The same authors report that a large number of business educators have banded together to protest AACSB's tepid stance on business ethics education.

Psychologists Silberzahn and Uhlmann (2015) recruited twenty-nine research teams to re-analyze a data set on referee bias in soccer, using methods of their choosing. They found the collective conclusion to be much more equivocal that any single team's interpretation. This is a valuable result. Their exploration of multi-team methodology as a new standard in psychology research, they concede, is less than promising: Efforts to turn psychology into "Big Science" are unlikely to be funded when it is seen that putting more resources into the study leads to more tentative results. The authors claim that the approach would reduce "the incentive for flashy results," though we see 
this effect as indirect at best - as would be its incentive for researchers to share data sets, which they are now widely reluctant to do. We wonder whether similar and cheaper results could be obtained by a single team using multiple methodologies to analyze their own data. Nonetheless, this study is a step toward reining in undisciplined research and publication.

More promising, but still in its infancy and a long way from influencing curriculum, is the Kavli project of Azmak et al. (2015). Subtitled "Using Big Data to Understand the Human Condition," the project follows "10,000 individuals whose biology and behavior will be measured using an unprecedented array of modalities over 20 years." It will yield "a complete record of the health, education, genetics, environmental, and lifestyle profiles of a large group of individuals at the within-subject level." Leveraging the multiple perspectives of several social and biological sciences, Kavli might unblock progress in the social sciences (while also providing frightening new tools for marketers).

We hope Brooks (2015) is correct in saying, "On almost every campus faculty members and administrators are trying to stem the careerist tide and to widen the system's narrow definition of achievement. Institutes are popping up - with interdisciplinary humanities programs and even meditation centers - designed to cultivate the whole student." Carlile et al. (2016) offer encouraging examples.

\section{Recommendations}

Business schools routinely preach radical innovation while discreetly neglecting to practice it. This self-imposed torpor... is frankly incredible.

- Martin Binks, Former Dean, Nottingham University Business School

1. Except for the most basic introductory courses, suspend all courses in social sciences (including economics) until those disciplines have reformed their tenets and practices. Alternatively and perhaps more practically, mandate immediate reform and revision of the courses. Teach the ways in which the different social sciences bring differing and sometimes opposing viewpoints on the same questions.

2. Ensure students are knowledgeable about, and able to express and debate their views on, current events in business.

3. Include more coursework in history and literature. Make Main Street and Barbarians at the Gate foundational to the curriculum. Do not let political pressures prevent teaching about the capital vs. labor tension that has had and continues to have such great impact on U.S. history.

4. Teach a variety of quantitative techniques - not just statistics. De-emphasize statistical technique, in favor of greater attention to research logic, study design, potential replicability, the possibility of different results in other demographics and other cultures, and other limits to a study's generalizability.

5. When introducing supply/demand curves, make it clear that their classic forms apply only to material commodities; that when the price of a financial product goes up, demand for it goes up, not down; and that information is yet a third market category, with increasing returns to scale, in that after I sell information, I still have it. Make 
room in the course for ideas from institutional, behavioral, and heterodox economics, from economic history, and the European tradition of empiricism in economics. Try not to perpetuate the cultural gulf between economics and econometrics.

6. Reform the language of business. "Management control," once an important activity, should be obsoleted, as it implies what is now an impossibility. "Royal Dutch Shell announced today that it is pulling the plug on all oil and gas exploration in the Arctic Ocean 'for the foreseeable future."'12 Let's recognize the future is not foreseeable, and that organizational flexibility is at least as important as forecasting. Sull et al. (2015) note that "resource allocation" implies a once-and-for-all distribution that is in opposition to the need for continuous agile re-allocation. In the 1990s, Japanese manufacturers gained competitive advantage by reducing fixed costs; this appears to be an impossibility in terms, until we learn that the Japanese term for such costs is "costs that do not vary with the level of production." The economic term "externalities" has been used to cover an embarrassing exclusion of important constituents from the analysis. Many other business terms beg for re-examination, so that their subtle implications will not lead students astray.

7. Grade students on their demonstrated ability to motivate and engage their classmates and team members.

8. De-emphasize teaching of traditional strategic planning, in favor of strategic alignment, fluid re-strategizing, and execution of strategies. Teach students how to "Experiment, iterate, and learn" (McGrath 2013).

9. B-schools should credit faculty, in their annual reviews, for contributions to curriculum that lead to solutions to the problems presented here. We might expect that major research universities can lead in this regard. However, that will not happen if faculty are rewarded only for publishing papers in " $\mathrm{A}$ " journals.

10. Stop giving faculty excess credit for single-authored papers. Recognize that the future is in team science (Falk-Krzesinski et al. 2011).

11. The accrediting agencies have a role to play in the re-invention of b-schools. They should encourage exploratory and experimental curriculum. They should re-think the "assurance of learning" guidelines that now so effectively assure that students have learned... the wrong things.

12. "Observational and anecdotal evidence suggests that business students are not only impaired in their moral judgments but that significant percentages of them have severely impaired moral imaginations. By this I mean not only do they make bad ethical decisions, but they actually are incapable of identifying an ethical situation when they are presented with one.... When business students are presented with .... a case where they have been told that there is an ethical problem, 20 to $30 \%$ of the students cannot find or identify the ethical issue" (Queen 2015). An 18-month MBA program cannot cure a sociopath. Rather than attempt it, B-schools might be advised to require applicants to substantiate a history of ethical decisions, and make the admission decision based upon that history. ${ }^{13}$ Hire faculty who will expect more from their students than just technical mastery.

13. Leading high tech companies design buildings that foster creative play, serendipitous interaction, and initiative. In this arena, business schools can learn from companies, getting rid of lecture halls with rigid furniture, and unattractive common spaces. 


\section{Conclusion}

\section{All told, the downside of an MBA outweighs the upside. - Guy Kawasaki ${ }^{14}$}

We opened this paper with Kurana's statement that there is no defined body of knowledge in management. Case in point: Citing Cazier and McInnis (2010) who found that the performance of companies after hiring a "star" CEO is inversely proportional to the performance of the companies they were hired from - in other words, that success in running one organization does not imply success in running another - The Economist ${ }^{15}$ asks, "Surely management skills are portable? What other justification is there for the giant MBA and executive-education businesses?"

Today's business school must decide its evidence-based mission, listening to and carefully balancing constituent groups' criticisms and desires, and redesign curriculum and faculty incentives in a way that moves that mission forward and puts students first. That is, if today's business school hopes to survive to be tomorrow's business school! In this paper we have detailed several of these constituent criticisms and desires, as well as the breakdown of prevailing theories, the perverse incentives put forth by accreditors and others, and the jobs-vs.-careers tensions that challenge our b-schools. We have noted a few constructive efforts directed at these challenges, and have offered our own recommendations. While the primary responsibility for improving business schools is the business schools, we believe all constituents own essential parts of the needed solutions, and in concert can craft effective actions.

The "torpor" noted by Martin Binks is not only "incredible," it is absolutely unsustainable. Medical schools influence the practice of medicine, and law schools the practice of law. It is only logical that business schools should influence the practice of business, meaning business scholars must be proactive thought leaders.

We drive our points home by quoting the strong words of two prominent business ethicists. In "An Open Letter to the Deans and the Faculties of American Business Schools," UC-Berkeley's Ian Mitroff (2004) writes,

I am writing to you because of the appalling and the sorry state of business schools. I am outraged over what we as business educators have allowed to develop. At best, we are guilty of having provided an environment where the Enrons and the Andersens of the world could take root and flourish. At worst, we are guilty of being active accomplices and co-conspirators in their shoddy and criminal behavior. In either case, unless we finally own up to the underlying reasons for our actions, business schools will only continue to aid and to abet the wave of scandals that have engulfed American businesses within the last few years.

From Edward L Queen (2015), Director of Ethics and Servant Leadership Program at Emory University, in the wake of the Volkswagen scandal ${ }^{16}$ :

That far too much of the world's corporate leadership is driven by moral midgets who have been educated far beyond their capacities for good judgment should be obvious after observing the events of the past week.... Data regularly demonstrates that business school students are more likely to cheat on examinations and 


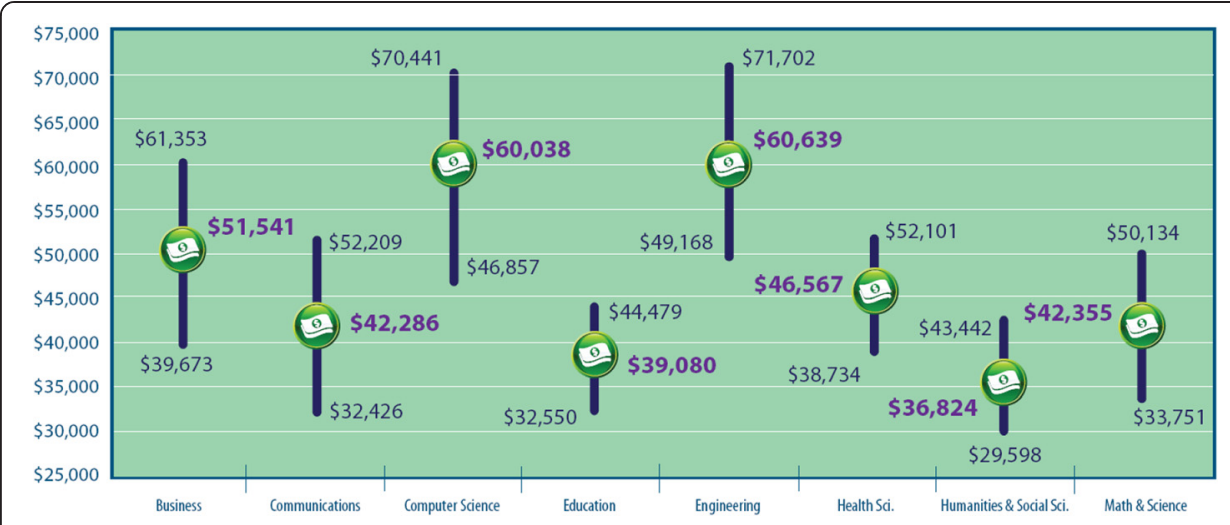

Fig. 1 Bachelor degree starting salaries in USA. Source: www.naceweb.org/salary-survey-data/

assignments than their [non-business major] peers.... Some evidence suggests that not only are business students more impaired in their moral judgments in a broader sense than are those in other majors and professional schools, but that business schools themselves (Swanson and Frederick 2002-2003) may be responsible.

We imagine a budding entrepreneur with $\$ 50,000$ in hand, wondering whether to use it to start a company, or to get an MBA. We imagine an alum with a five- or six-figure student loan debt, wondering whether business school was worth it. Another prospective student may read Fitz' (2015) Scientific American article "Economic Inequality: It's Far Worse Than You Think," and conclude that the sheer probability of ending up on the right side of America's inequality gap makes an expensive MBA a fool's gamble. ${ }^{17}$ We ask ourselves, why would an employer pay more for someone who has a MBA, when a BA plus some work experience might suffice? A high school senior might note the starting salary potential is much higher in computer science or engineering than for business majors (Fig. 1). She or he might choose business anyway because it's perceived to be "easier" than engineering. Is it easier because there is no consensus body of knowledge and teaching is scattershot?

Given the above indictments of b-schools, it is not hard to predict how these decisions will begin to tilt against university enrollments - unless something is done. We have presented a list of recommendations that, though perhaps radical, should be seen only as a starting point toward remediating the crises and rehabilitating the business schools.

Most of our b-school experience is with, and our remarks in this paper are primarily directed at, U.S. business schools. Our visits to non-US schools suggest that while they do some things better and some things worse, they share many of the same problems as their U.S. sister schools. ${ }^{18}$ Their possible remedies will be different from U.S. schools', due to local cultures and laws, and we do not attempt to address them here.

Perhaps like most business faculty, the present authors have been inspired by many aspects of our b-school careers and horrified by others. We hope that this report will help to bring about needed discussion and change.

\section{Endnotes}

${ }^{1}$ One honest, frank exception is Jamie Galbraith, an economist who after the crash testified to a Congressional committee that his is a "disgraced profession." www.zerohedge.com/article/james-galbraith-economic-theory-disgraced-profession 
"Most management schools are reporting a decline in the number of applicants for their two-year MBA programs... students are flocking to one-year specialized degrees." http://strategy-business.com/article/00164?pg = all

${ }^{3}$ https://www.foreignaffairs.com/articles/united-states/2015-03-05/defense-financialinnovation

${ }^{4}$ http://theantimedia.org/big-banks-fined-5-7-billion-after-pleading-guilty-to-globalcurrency-conspiracy/

${ }^{5}$ www.bizedmagazine.com/your-turn/reflections-of-an-ex-dean/?utm_source=HighRo ads\%20Solutions\&amp;utm_ medium=Email\&amp;utm_campaign=HighRoads\%20All\%20Emails

${ }^{6}$ Atkinson and Lind note that Schumpeter agreed with them: A system which is efficient in the static sense at every point in time can be inferior to a system which is never efficient in this sense, because the reason for its static inefficiency can be the driver for its long-term performance.'

${ }^{7}$ http://www.thelowdownblog.com/2015/03/tech-is-desperate-for-new-people-

but.html?utm_source=feedburner\&utm_medium =email\&utm_campaign=Feed\%3A

+TheLow-down+\%28The+Low-Down\%29

${ }^{8}$ http://www.science20.com/machines_organizations_and_us_sociotechnical_systems/ cui_bono_bcorporations_and_the_university-148228

${ }^{9}$ http://www.fastcompany.com/3046299/the-new-rules-of-work/this-is-the-future-ofcollege?utm_content=buffere36a4\&utm_medium=social\&utm_source=linkedin.com \& utm_campaign=buffer

${ }^{10}$ https://biggernumbers.wordpress.com/macro-matters/

${ }^{11} \mathrm{Or}$, sometimes, against industry's gross hypocrisy. For-profit universities obviously are businesses, but they depend on appropriations (in the form of federal student aid) from governments. I.e., their model is very much like state institutions', but all too often less law-abiding, and in abdication of any duty to students. As Slate and InsideHigherEd have now helped propagate the meme that the wealthiest private non-profit universities are "hedge funds with universities attached for tax purposes," we may conclude that many of these institutions are indeed run like businesses. "The only difference between Stanford and Google is we have a higher profit margin," says Stanford GSB Professor Jeffrey Pfeffer (www.bloomberg.com/news/features/2015-10-07/a-sex-scandal-rocks-stanford-s-business-school). The operating model challenge we describe in this section is faced mostly by state universities.

${ }^{12}$ http://grist.org/politics/shell-just-abandoned-its-arctic-drilling-plans/

${ }^{13}$ Serial CEO Margaret Heffernan makes a reasonable rebuttal of the "the executive suite disproportionately attracts psychopaths" theory, at http://www.cbsnews.com/ news/are-ceos-psychopaths/

${ }^{14}$ http://guykawasaki.com/the_venture_cap/

${ }^{15}$ http://www.economist.com/node/21530953

${ }^{16}$ In 2015 it was revealed that diesel Volkswagens contain software to detect when an emissions test is underway, and to decrease the engine's output of pollutants for the duration of the test.

${ }^{17}$ An articulate blog (Alptraum 2016) details one prospective grad student's reasoning on this question.

${ }^{18}$ Smith (2015) reports, “Japan's government just ordered all of the country's public universities to end education in the social sciences, the humanities and law". 


\section{Competing interests}

The authors declare that they have no competing interests.

\section{Authors' contributions}

All authors contributed to the literature search and interpretation. FP drafted the manuscript. All authors read and approved the final manuscript.

\section{Acknowledgement}

The authors thank Sehee Kim, Hyojung Lee, Daniel Soonwoo Chang, and Brian Kim for initial research assistance.

\section{Disclaimer}

Opinions expressed herein are those of the authors and interviewees, and do not necessarily reflect institutional views of the authors' employers.

Linda Golden is Marlene and Morton Meyerson Centennial Professor in Business at the University of Texas at Austin's McCombs School of Business. She is a Faculty Fellow at UT-Austin's Humanities Institute and a Senior Fellow of the IC ${ }^{2}$ Institute.

Chih-Hung Hsieh is Associate Professor and Director of MBA and PhD programs at Yuan Ze University, Taoyuan, Taiwan.

Charles Ingene is Siegfried Centennial Professor of Marketing \& Supply Chain Management at the University of Oklahoma, Norman.

Fred Phillips is Distinguished Professor at Yuan Ze University's College of Management, where he is Head of the International College. He is a Visiting Professor at SUNY Stony Brook, a Senior Fellow of the University of Texas at Austin's IC Institute, and Editor-in-Chief of Elsevier's Technological Forecasting \& Social Change.

\section{Author details}

${ }^{1}$ Stony Brook University, Stony Brook, USA. ${ }^{2}$ Yuan Ze University, Taoyuan City, Taiwan. ${ }^{3}$ University of Oklahoma, Norman, USA. ${ }^{4}$ University of Texas at Austin, Austin, USA.

Received: 24 May 2016 Accepted: 25 June 2016

Published online: 30 July 2016

\section{References}

Alptraum, L. (2016). Millennials, please don't waste your money on graduate school. May 11, http://qz.com/680954/ millennials-please-dont-waste-your-money-on-graduate-school/. Accessed 17 July 2016

Anders, G. (2015). That 'Useless' liberal arts degree has become Tech's hottest ticket. Forbes, JUL 29. http://www.forbes. com/sites/georgeanders/2015/07/29/liberal-arts-degree-tech/. Accessed 17 July 2016.

Atkinson, R., \& Lind, M. (2013). Econ 101 is killing America. Salon, http://www.salon.com/2013/07/08/how_"econ_ 101"_is_killing_america/. Accessed 17 July 2016.

Azmak, O., Bayer, H., Caplin, A., Chun, M., Glimcher, P., Koonin, S., \& Patrinos, A. (2015). Using big data to understand the human condition: The Kavli HUMAN Project. Big Data, 3(3), 173-188. http://doi.org/10.1089/big.2015.0012.

Benton, T. H. (2008). On stupidity. The Chronicle of Higher Education. http://chronicle.com/article/On-Stupidity/45764 (accessed September 15, 2010)

Bloom, N., Sadun, R., \& Van Reenen, J. (2012). Does management really work? Harvard Business Review (November), 1-7.

Brooks, D. (2015). The Big University. New York Times, Oct. 6. http://www.nytimes.com/2015/10/06/opinion/david-brooks-thebig-university.html?smid=li-share\&_r=0. Accessed 17 July 2016.

Bradshaw, D. (2015). Short tenure of deans signals a leadership void. Financial Times, April 26, http://www.ft.com/intl/ cms/s/2/8af77ab4-e442-11e4-9039-00144feab7de.html\#axzz48UwjO3Vf. Accessed 17 July 2016.

Calacanis, J. (2015). Apple's brilliant assault on advertising - and Google. Sep 25. Blog at https://www.linkedin.com/pulse/ apples-brilliant-assault-advertising-google-jason-calacanis. Accessed 17 July 2016.

Carlile, P. R., Davidson, S. H., Freeman, K. W., Thomas, H., \& Venkatraman, N. (2016). Reimagining business education: insights and actions from the business education jam. Bingley: Emerald.

Cazier, R. A., \& McInnis, J. M. (2010). Do firms contract efficiently on past performance when hiring external CEO's? SSRN Electronic Journal, http://doi.org/10.2139/ssrn.1732754.

Coates, J. F. (1994). Ethics, the new plague on American civilization. Technological Forecasting and Social Change, $47(3), 345-350$

Davies, H. (2012). Economics in denial. Project Syndicate, Retrieved from http://www.project-syndicate.org/commentary/ economics-in-denial-by-howard-davies. Accessed 17 July 2016.

DeLong, J. B. (2011). Economics in crisis. Project Syndicate, Retrieved from http://www.project-syndicate.org/ commentary/economics-in-crisis. Accessed 17 July 2016.

Denning, S. (2012). What killed Michael Porter's Monitor Group? The one force that really matters. Forbes. Retrieved from http://www.forbes.com/sites/stevedenning/2012/11/20/what-killed-michael-porters-monitor-group-the-one-forcethat-really-matters/. Accessed 17 July 2016.

Falk-Krzesinski, H. J., Contractor, N., Fiore, S. M., Hall, K. L., Kane, C., Keyton, J., ... Trochim, W. (2011). Mapping a research agenda for the science of team science. Research Evaluation, 20(2), 143-156.

Fall, L., \& Gaposchkin, C. (2015). A safer health-care system starts with the liberal arts. Pacific Standard, September 29. http://www.psmag.com/health-and-behavior/a-safer-health-care-system-starts-with-the-liberal-arts. Accessed 17 July 2016 .

Feintzeig, R. (2015). Companies fast track hiring. Wall Street Journal. Sept. 16. http://www.wsj.com/articles/companiesfast-track-hiring-1442395981. Accessed 17 July 2016. 
Fitz, N. S. (2015). Economic inequality: It's far worse than you think. Scientific American: Mind \& Brain, (On-line, March 31), 1-3. Retrieved from http://www.scientificamerican.com/article/economic-inequality-it-s-far-worse-than-you-think/. Accessed 17 July 2016.

Foroohar, R. (2014). Wall Street's values are strangling american business (p. 15). TIME, July 21.

Frick, W. (2015). Are successful CEOs just lucky? Harvard Business Review, Nov. 16. https:/hbr.org/2015/11/are-successful-ceos-just-lucky. Accessed 17 July 2016

Galbraith, J. K. (2010). Why the "Experts" failed to see how financial fraud collapsed the economy. AlterNet.

Henrich, J., Boyd, R., Camerer, C. F., Bowles, S., Herbert Gintis, Fehr, E., ... Tracer, D. (2005). "Economic Man" in crosscultural perspective: Behavioral experiments in 15 small-scale societies. Behavioral and Brain Sciences, 28, $795-855$. http://doi.org/10.1017/S0140525X05000142.

Henrich, J., Heine, S. J., \& Norenzayan, A. (2010). The weirdest people in the world? The Behavioral and Brain Sciences, 33(2-3), 61-83. discussion 83-135. http://doi.org/10.1017/S0140525X0999152X.

Holstein, W. J. (2013). The Multipolar MBA. Strategy+business.

Howard-Grenville, J., Buckle, S. J., Hoskins, B. J., \& George, G. (2014). Climate change and management. Academy of Management Journal, 57, 615-623.

Konczal, M. (2015). The future of work: the (excessive) power of finance. Pacific Standard, Oct. 6. http://www.psmag.com/ business-economics/the-future-of-work-the-excessive-power-of-finance. Accessed 17 July 2016.

Krugman, P. (2011). The profession and the crisis. Eastern Economic Journal, 37(3), 307-312. http://link.springer.com/ article/10.1057/eej.2011.8, Accessed 17 July 2016.

Lashinsky, A. (2015). Apple's Tim Cook leads different. Fortune, March 26, http://fortune.com/2015/03/26/tim-cook/. Accessed 17 July 2016.

Linstone, H. A., \& Mitroff, I. I. (1994). The challenge of the 21st century: managing technology and ourselves in a shrinking world. Albany: State University of New York Press.

Mathewson, T. G. (2015). Higher education: lifetime training or a path to the next job? Retrieved July 18, 2016, from http://www.educationdive.com/news/higher-education-lifetime-training-or-a-path-to-the-next-job/406236/.

McGrath, R. G. (2013). Transient advantage. Harvard Business Review. June. https://hbr.org/2013/06/transient-advantage. Accessed 17 July 2016.

Mims, C. (2015). The dangers ahead if tech unicorns get gored. Wall Street Journal, Oct. 26. http://www.wsj.com/articles/ the-dangers-ahead-if-tech-unicorns-get-gored-1445832492. Accessed 17 July 2016.

Mitroff, I. (2004). An open letter to the deans and the faculties of american business schools. Journal of Business Ethics, 54(2), 185-189. doi:10.1007/s10551-004-9462-y.

Mulcahy, D., Weeks, B., \& Bradley, H. S. (2012). We have met the enemy... and he is us: lessons from twenty years of the Kauffman Foundation's Investments in Venture Capital Funds and The Triumph of Hope over Experience. Retrieved from http://www. kauffman.org/ /media/kauffman_org/research reports and covers/2012/05/we_have_met_the_enemy_and_he_is_us.pdf. Accessed 17 July 2016.

Mukunda, G. (2014). The price of Wall Street's power. Harvard Business Review, June. https://hbr.org/2014/06/the-price-ofwall-streets-power/ar/1. Accessed 17 July 2016.

News Staff. (2015). Is failure to reproduce psychology papers a sign they are invalid? Science 2.0, September 1. http:// www.science20.com/news_articles/is_failure_to_reproduce_psychology_papers_a_sign_they_are_invalid-156999. Accessed 17 July 2016.

Otani, A. (2015). Half of all us employees quit their jobs to get away from bad bosses. Bloomberg. http://www. thelowdownblog.com/2015/04/half-of-all-us-employees-quit-their.html. Accessed 17 July 2016.

Phillips, F. (2006). The business school in a time of transition. In F. Phillips (Ed.), Social culture and high tech economic development: the technopolis columns (Vol. Chapter 4). London: Palgrave Macmillan.

Phillips, F. (2014). Meta-measures for technology and environment. Foresight, 16(5), 410-431.

Queen, E. L. (2015). Business schools breed unethical businessmen. New Republic, Sept. 28, http://www.newrepublic.com/ article/122940/business-schools-breed-unethical-businessmen. Accessed 17 July 2016.

Rao, V. (2012). Entrepreneurs are the New Labor. Forbes, Sept. 3. http://www.forbes.com/sites/venkateshrao/2012/09/03/ entrepreneurs-are-the-new-labor-part-i/. Accessed 17 July 2016.

Rawlings, H. R. I. I. I. (2016). What's right and wrong about research universities. Inside Higher Ed. May 10. https://www. insidehighered.com/views/2016/05/10/former-association-president-muses-research-universities-today-essay?utm_ source=Inside+Higher+Ed\&utm_campaign=56acbba5bb-DNU20160510\&utm_medium=email\&utm_term=0_ 1fcbc04421-56acbba5bb-197749637\#.VzGmJl6NnUw.linkedin. Accessed 17 July 2016.

Riddell, R. (2016). Retiring AAC\&U president makes case for broad liberal arts education. Education Dive. May 12, http:// www.educationdive.com/news/retiring-aacu-president-makes-case-for-broad-liberal-arts-education/419107/. Accessed 17 July 2016.

Roush, Andew (2015) First Impressions. Alcalde. Sept-Oct, pp30-31.

Satell, G. (2015). Why big organizations are broken. Digital Tonto, March 22 http://www.digitaltonto.com/2015/why-bigorganizations-are-broken/. Accessed 17 July 2016

Shea, C. (2011). Fraud scandal fuels debate over practices of social psychology. Chronicle of Higher Education. Retrieved from http://chronicle.com/article/As-Dutch-Research-Scandal/129746/?sid=pm\&utm_source=p. Accessed 17 July 2016.

Silberzahn, R., \& Uhlmann, E. L. (2015). Many hands make light work. Nature, 526, 189-191. http:/www.nature.com/news/ crowdsourced-research-many-hands-make-tight-work-1.18508, Accessed 17 July 2016.

Skidelsky, R. (2012). Models behaving badly. Project Syndicate. December 18. www.project-syndicate.org\%2Fcommentary \%2Fwhy-forecasts-of-economic-recovery-have-been-wrong-by-robert-skidelsky\&usg=AFQjCNFmhWkc2HhJk5BEc Gbe4An5xRYOhA. Accessed 17 July 2016.

Slaughter, A.-M. (2015). A toxic work world. New York Times Sunday Review, (September 27), 1-6. Retrieved from http:// www.nytimes.com/2015/09/20/opinion/sunday/a-toxic-work-world.html. Accessed 17 July 2016.

Smith, N. (2015). Japan dumbs down its universities. Bloomberg, SEPT 20. http://www.bloombergview.com/articles/201509-20/japan-dumbs-down-its-universities-at-the-wrong-time. Accessed 17 July 2016. 
Stacey, Ralph D (2009) Complexity and organizational reality: uncertainty and the need to rethink management after the collapse of investment capitalism. Routledge. 2nd Ed.

Sull, D. (2015). Rebecca Homkes and Charles Sull why strategy execution unravels - and What to do about it. Harvard Business Review. March. https://hbr.org/2015/03/why-strategy-execution-unravelsand-what-to-do-about-it. Accessed 17 July 2016

Swanson, D. L., \& Frederick, W. C. (2003). Are business schools silent partners in corporate crime. Journal of Corporate Citizenship, 9(Spring), 24-27.

Swanson, D. L., \& Frederick, W. C. (2002-2003). Campaign AACSB: Are business schools complicit in corporate corruption?". Journal of Individual Employment Rights, 10(2), 151-165.

Swanson, D. L., \& Frederick, W. C. (2015). Commentary on: Are business schools silent partners in corporate crime? In M. McIntosh (Ed.), Published in business, capitalism and corporate citizenship (pp. 74-79). Sheffield: Greenleaf Publishing.

van Noorden, R. (2015). Interdisciplinary research by the numbers. Nature. Sept. 16. www.nature.com/news/ interdisciplinary-research-by-the-numbers-1.18349. Accessed 17 July 2016.

Watters, E. (2013). We aren't the world. Pacific Standard. Santa Barbara. http://www.psmag.com/books-and-culture/joehenrich-weird-ultimatum-game-shaking-up-psychology-economics-53135. Accessed 17 July 2016.

Wheelan, B. S., \& Elgart, M. A. (2015). Accreditation's real cost (and Value). October 22. https://www.insidehighered.com/ views/2015/10/22/real-costs-accreditation-and-processs-value-essay?utm_content=buffer28257\&utm_ medium=social\&utm_source=linkedin.com\&utm_campaign=buffer. Accessed 17 July 2016.

Zingales, L. (2015). Does finance benefit society? (No. JEL \# G00,O43). Retrieved from http://papers.nber.org/tmp/ 51077-w20894.pdf. Accessed 17 July 2016.

\section{Submit your manuscript to a SpringerOpen ${ }^{\circ}$ journal and benefit from:}

- Convenient online submission

- Rigorous peer review

- Immediate publication on acceptance

- Open access: articles freely available online

- High visibility within the field

- Retaining the copyright to your article

Submit your next manuscript at $\boldsymbol{\wedge}$ springeropen.com 